\title{
Design of Protected Area by Tracking and Excluding the Effects of Climate and Landscape Change: A Case Study Using Neurergus derjugini
}

\author{
Somaye Vaissi (D)
}

check for updates

Citation: Vaissi, S. Design of Protected Area by Tracking and Excluding the Effects of Climate and Landscape Change: A Case Study Using Neurergus derjugini. Sustainability 2021, 13, 5645. https://doi.org/10.3390/ su13105645

\section{Academic Editors:}

Kinga Kostrakiewicz-Gierałt and Artur Pliszko

Received: 13 April 2021

Accepted: 17 May 2021

Published: 18 May 2021

Publisher's Note: MDPI stays neutral with regard to jurisdictional claims in published maps and institutional affiliations.

Copyright: (C) 2021 by the author. Licensee MDPI, Basel, Switzerland. This article is an open access article distributed under the terms and conditions of the Creative Commons Attribution (CC BY) license (https:// creativecommons.org/licenses/by/ $4.0 /)$.
Department of Biology, Faculty of Science, Baghabrisham, Razi University, Kermanshah 6714414971, Iran; s.vaissi@razi.ac.ir

\begin{abstract}
This study aimed to use the applications of Ensemble Species Distribution Modelling (eSDM), Geographical Information Systems (GISs), and Multi-Criteria Decision Analysis (MCDA) for the design of a protected area (PA) for the critically endangered yellow-spotted mountain newt, Neurergus derjugini, by tracking and excluding the effects of climate and landscape changes in western Iran and northeastern Iraq. Potential recent and future distributions (2050 and 2070) were reconstructed by eSDM using eight algorithms with MRI-CGCM3 and CCSM4 models. The GIS-based MCDA siting procedure was followed inside habitats with high eSDM suitability by eliminating the main roads, cities, high village density, dams, poor vegetation, low stream density, agricultural lands and high ridge density. Then, within the remaining relevant areas, 10 polygons were created as "nominations" for PAs (NPAs). Finally, for 10 different NPAs, the suitability score was ranked based on ratings and weights (analytical hierarchy process) of the number of newt localities, NPA connectivity, NPA shape, NPA habitat suitability in 2070, NPA size, genetic diversity, village density and distance to nearest PAs, cities, and main roads. This research could serve as a modern realistic approach for environmental management to plan conservation areas using a cost-effective and affordable technique.
\end{abstract}

Keywords: amphibian; conservation; endangered species; ensemble species distribution model; GIS; multi-criteria decision analysis

\section{Introduction}

Amphibians are valuable components of biodiversity that have declined significantly in many regions of the world [1-3]. Extrinsic reasons that have contributed to these declines include several biotic and abiotic factors that act synergistically, such as habitat loss and fragmentation [4], chemical pollutions [5], UV radiation [6], alien species [7], direct exploitation [8], disease [9] and climate change [10]. For all of these reasons, the in situ conservation of viable populations in natural ecosystems is an essential strategy for managing and monitoring amphibian communities [11]. However, amphibians are often neglected for conservation efforts, and only $\leq 5 \%$ of $42 \%$ of threatened species are found in the protected areas (PAs hereafter) [12,13]. Although, the establishment and management of global PAs to conserve biodiversity at the lowest possible cost are accepted according to conservation policies [14].

A review of various studies has shown that climate change [15-20] and landscape change [21-28] are two critical factors that affect PAs but, to date, few studies have specifically considered how to design a new PA by excluding these emerging threats. Changes in habitat extent, as well as landscape and habitat structure due to human activities such as urbanization [29,30], intensive agriculture [31,32] and roads [33,34], have negative consequences on the abundance and distribution of amphibians [35]. Landscape fragmentation reduces connectivity and genetic diversity among populations [36], which is followed by decreasing fitness and increased risk of local extinction [37]. 
Climate change has been known as a significant emerging issue for PAs during the recent decade [15-20]. Based on the findings, the average global temperature has increased by $0.2{ }^{\circ} \mathrm{C}$ per decade since 1970 , and the average global precipitation has increased by $2 \%$ in the last 100 years [38]. Amphibians are vulnerable to climate change due to their unshelled eggs, extremely permeable skin, and biphasic life cycles [39]. It has been shown that with the increase in mean temperatures, the body condition of amphibians decreases, and, subsequently, fecundity decreases [40]. On the other hand, wetland desiccation caused by climate change has been followed by the disappearances of amphibian species [41]. Climate change may also change the geographic ranges of species by shifts in longitude, latitude, and altitude [42-45].

This study focused on the yellow-spotted mountain newt, Neurergus derjugini (previously known as N. microspilotus), using reports from 57 streams, springs, human-made pools, and irrigation channels located adjacent to first-order streams in the Zagros mountains in western Iran and northeastern Iraq [46-56]. The International Union for Conservation of Nature (IUCN) listed this species as critically endangered (A3cde+4cde; $\mathrm{B} 2 \mathrm{ab}(\mathrm{iii}, \mathrm{iv}, \mathrm{v}))$ due to a small reproductive area $\left(\leq 10 \mathrm{~km}^{2}\right)$, habitat loss and fragmentation, agriculture and aquaculture activities, dam constructions, road fatalities, pollutions, climate change, ecotourism and local, national, international trades [57-59]. Nearly 71.92\% $(\mathrm{N}=41)$ of the known habitats for $N$. derjugini are in Iran and $28.07 \%(\mathrm{~N}=16)$ are in Iraq. More than $50 \%$ of these habitats are located $10 \mathrm{~km}$ across the Iraqi-Iranian border. The distribution area of $N$. derjugini using a minimum convex polygon including all sites $(\mathrm{N}=57)$ is about $10,421 \mathrm{~km}^{2}$ (based on new assessments made in the present study). This polygon is located along the western edge of the Zagros mountains at an altitude of 630 to $2057 \mathrm{~m}$ above sea level that is covered by orchards, open woodlands, scrublands, grasslands, and farmlands [55].

This research aimed to use the application of Ensemble Species Distribution Modelling (eSDM hereafter), Geographical Information Systems (GISs hereafter), and Multi-Criteria Decision Analysis (MCDA hereafter) for the design of a PA by tracking and excluding the effect of climate and landscape changes in western Iran and northeastern Iraq. The target of this study, in addition to conserving the studied species, is to provide a new practical method to establish priorities in the management and conservation of PAs through an economical and affordable methodology for environmental managers [60-67]. Three specific objectives have been developed for this purpose: (1) developing the eSDM to predicted recent and future (2050 and 2070) climate projections under optimistic (RCP26) and pessimistic (RCP85) scenarios; (2) establishing GIS-based data implicating spatially georeferenced information; (3) using an MCDA system to rank nominated protected areas (NPAs hereafter) numerically.

\section{Materials and Methods}

\subsection{The Study Area and Occurrence Points}

The study areas are located in western Iran (Kermanshah, Kurdistan, and West Azerbaijan provinces) and northeastern Iraq (Sulaymaniyah province, Iraq) (Figure 1). In these areas, 57 occurrence records of $N$. derjugini were obtained from different resources: Nesterov [46], Schmidtler and Schmidtler [47], Sharifi and Assadian [48], Najafimajd and Kaya [49], Schneider and Schneider [50], Naderi [51], Al-Sheikhly, Iyad, Rastegar-Pouyani and Browne [52], Rastegar-Pouyani, Mirani, Bahmani, Karamiani, Takesh and Browne [53], Afroosheh, Akmali, Esmaili and Sharifi [55], Zarei, Hosseini, Amini, Pezeshk, Soofi and Esmaeili [54] and Mawloudi, Rastegar-Pouyani and Rastegar-Pouyani [56] (Supplementary Materials Table S1, Figure 1). Table S1 lists the localities, latitudes, and longitude of occurrence points, as well as their references. The minimum distance between the occurrence points was $910 \mathrm{~m}$ and the maximum distance was $120 \mathrm{~km}$. The average migration distance in $N$. derjugini is about $49.19 \pm 71.75 \mathrm{~m}$ [68]. For this reason, all 57 data points were used for the distribution modelling approach. The methodology employed in various stages in the siting procedures for selecting protected areas for N. derjugini is illustrated in Figure 2. 


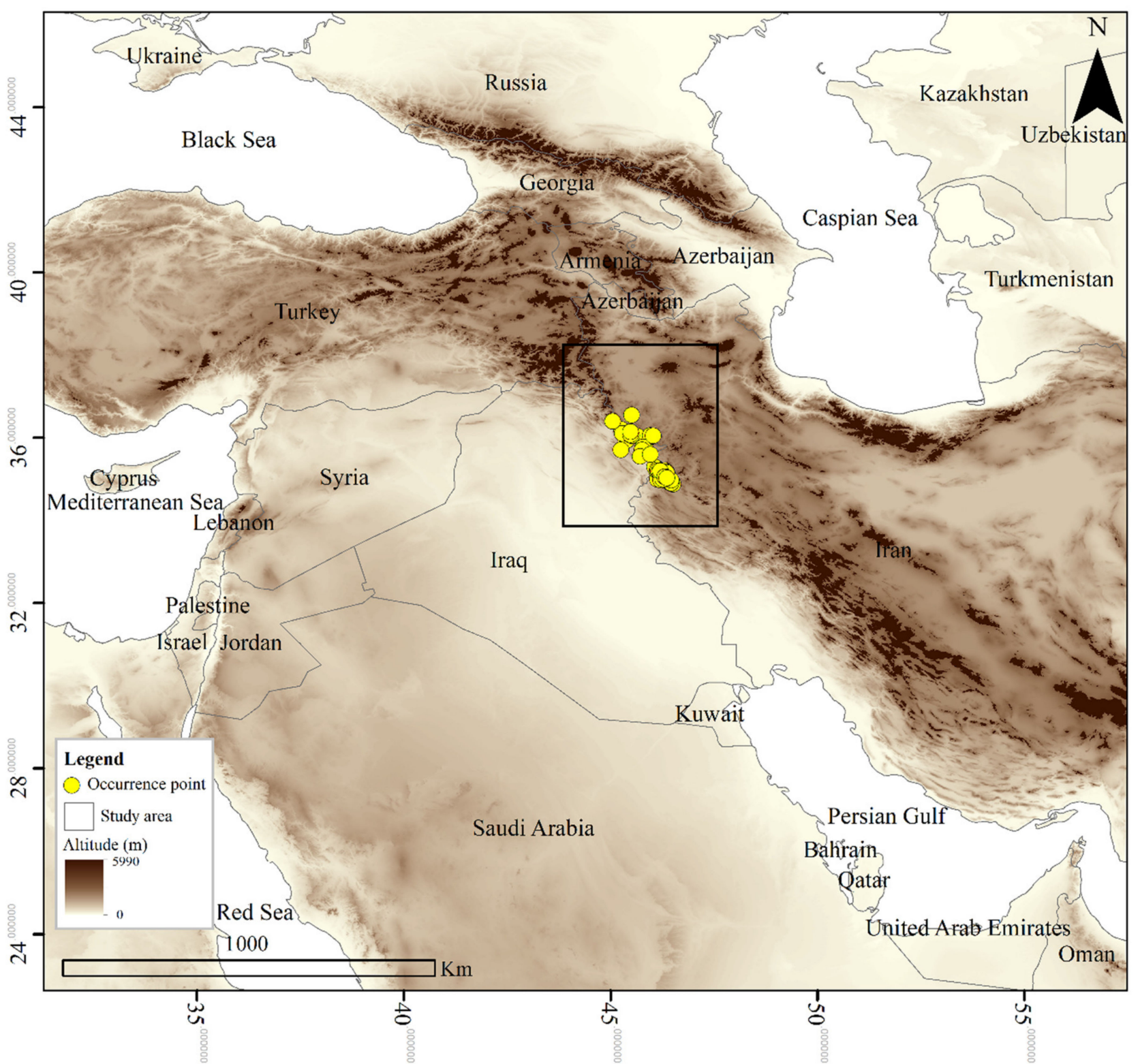

Figure 1. Study area. Location and distribution points (yellow-circles) of yellow-spotted mountain newt, Neurergus derjugini in western Iran and northeastern Iraq.

\subsection{Environmental Data}

To reconstruct recent and future (2050 and 2070) climate projections under optimistic (RCP26) and pessimistic (RCP85) scenarios, 19 bioclimatic variables with $30 \mathrm{~s}$ spatial resolution were downloaded from the WorldClim-Global Climate data (https: / / www. worldclim.org; accessed on 5 March 2021). Climatic data for 2050 and 2070 were derived from two atmospheric circulation models (ACMs): Community Climate System Model Version 4 (CCSM4; see Gent et al. [69]) and Meteorological Research Institute CGCM Version 3 (MRI-CGCM3; see Yukimoto et al. [70]). The CCSM4 is widely used for predicting climate change effects on fauna distribution in Iran, for example, [71-74]. The MRI-CGCM3 has also been suggested as one of the best models from 37 Coupled Model Intercomparison Project phase 5 (CMIP5) General Circulation Models (GCMs) of regional climate change projections in Iran [75]. Due to the high correlation between bioclimatic variables and preventing any potential collinearity problems, the Pearson correlations for 19 climatic variables were evaluated using SPSS software (v 22.0), and only variables with a correlation 
less than $(\mathrm{r}<0.75)$ were used for analysis. The models were eventually run using six bioclimatic variables: annual mean temperature (BIO1); mean diurnal range (mean of monthly (max temp-min temp)) (BIO2); temperature seasonality (standard deviation $\times 100)(\mathrm{BIO} 4)$; annual precipitation (BIO12); precipitation of wettest month (BIO13) and precipitation of driest month (BIO14).

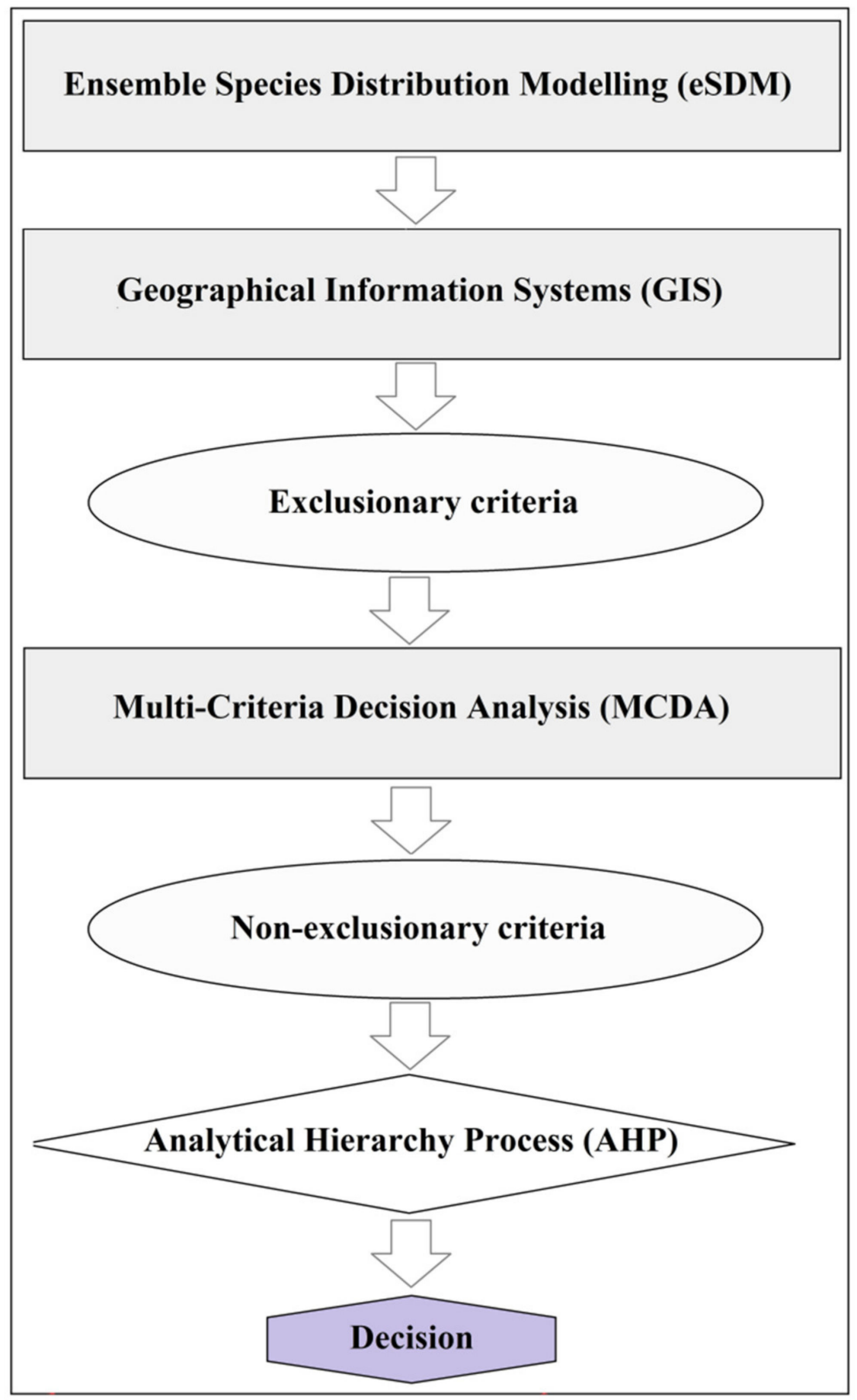

Figure 2. A figure illustrating the methodology used in various stages in the siting procedures for selecting nominated protected areas (NPAs) for yellow-spotted mountain newt, Neurergus derjugini, in western Iran and northeastern Iraq. 


\subsection{Ensemble Species Distribution Modelling (eSDM)}

BIOMOD2 package in R v 4.0.30 was used for Ensemble Species Distribution Modelling (eSDM) [76]. Eight algorithms were run: Generalized Linear Models (GLMs), Generalized Boosted Models (GBMs), Random Forest (RF), Classification Tree Analysis (CTA), Artificial Neural Networks (ANNs), Surface Range Envelopes (SREs), Flexible Discriminant Analysis (FDA) and Multivariate Adaptive Regression Splines (MARSs). These models are based on the presence-absence algorithms, and since the absence records were not available, pseudo-absence records, with a number equal to the records of presence, were randomly generated for each model [77,78]. For each model, $80 \%$ (training set) of the data were randomly assigned for model calibration and $20 \%$ (validation set) for the performance of the algorithms [79]. Every model algorithm was run ten times to eliminate bias caused by the splitting of the total records [80]. Each model was evaluated by the true skill statistic (TSS), receiver operating characteristic curve $($ ROC or $=$ AUC), and Cohen's Kappa (KAPPA) metrics (see Supplementary Materials Scripts S1 for more details). However, TSS $\geq 0.8$ was kept to build the final ensemble [79]. Species range change (SRC) was also used to quantify and represent geographical change over time (Scripts S1) [79].

\subsection{Siting Procedure}

\subsubsection{Data Type and Sources}

Iran and Iraq digital elevation model (DEM) with a $30 \mathrm{~s}$ spatial resolution $(\sim 1 \mathrm{~km})$ was downloaded from WorldClim. An Iran land cover map, including data of urban, water, forest, farmland, rangeland, shrubland, uncovered plain (bareland) with a spatial resolution of $10 \mathrm{~m}$, was downloaded from Google Earth Engine (GEE) (https: / / earthengine. google.com; accessed on 5 March 2021) [81]. Iran's main roads, villages and protected areas with a $30 \mathrm{~m}$ resolution were obtained from the Iranian Forest, Rangeland, and Watershed Management Organization [82]. Iran and Iraq stream layers were created by the DEM layer in GIS. Data of Iraq villages were created by Google Earth Pro. Iraq land cover and the main rod with a $30 \mathrm{~s}$ spatial resolution $(\sim 1 \mathrm{~km})$ were downloaded from the United States Geological Survey (USGS: https: / /www.usgs.gov; accessed on 5 March 2021) and Diva-GIS (http:/ / www.diva-gis.org; accessed on 5 March 2021).

\subsubsection{Geographic Information System (GIS)}

The siting procedure was followed in three stages. After obtaining the eSDM results, in the first stage, based on habitat suitability (HS hereafter), N. derjugini habitats are classified into four classes including habitats with extremely high suitability $(75-100 \%)$, high suitability $(50-75 \%)$, medium suitability $(25-50 \%)$ and low suitability $(0-25 \%)$ for the present and the years 2050 and 2070. For the current habitat suitability, a polygon has been created around habitats with high and very high (50 to 100\%) suitability (Figure 3 ). This polygon was used as a study area for the multi-criteria decision analysis (MCDA) based on the GIS siting procedure (Figure 3).

The exclusionary criteria were then applied. The exclusionary criteria were considered as significant factors and were assumed to damage the abundance of $N$. derjugini if they are within or close to a PA. Supplementary Materials Table S2 listed the exclusionary criteria as well as a brief explanation of why they are important to choose. Therefore, within the study area, all main roads, all cities, all dams, areas with poor vegetation, farmlands (concretely irrigated lands), and elevations above $2500 \mathrm{~m}$ were excluded. The streams were classified into five classes with very low, low, medium, high, and very high densities and the very low density areas of the streams $\left(\leq 0.03 \mathrm{~km}^{2}\right)$ were excluded from the study area. The villages were also classified into two classes with low and high densities and the high density areas of the villages $\left(\geq 0.72 \mathrm{~km}^{2}\right)$ were excluded from the study area. After deleting the exclusionary criteria from the study area, 10 polygons were created in the remaining areas, especially in the areas where $N$. derjugini were present. These polygons were considered as "nominations" for the protected areas (NPAs hereafter) in the MCDA analysis. It should be noted that dry farming and gardens are the key activities of the people in these regions, 
and they covered the majority of the study areas. As a result, although they are depicted in Figure 4, they were not considered when designing the PA and only irrigated agricultural lands were taken into account.

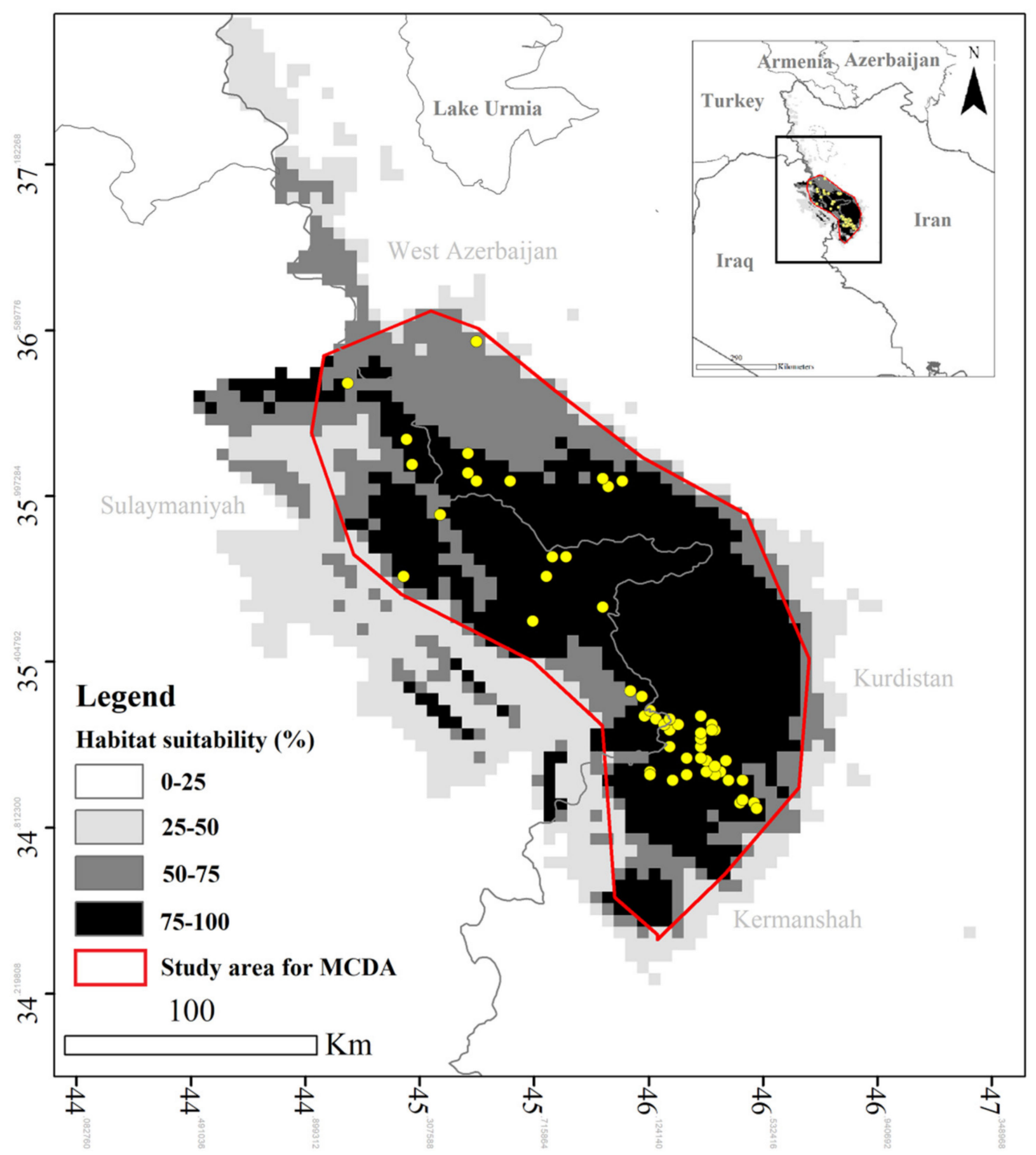

Figure 3. Current habitat suitability (\%) for Neurergus derjugini based on the consensus model in western Iran and northeastern Iraq. The red polygon represents the study area for the Multi-Criteria Decision Analysis (MCDA) based on the GIS. 


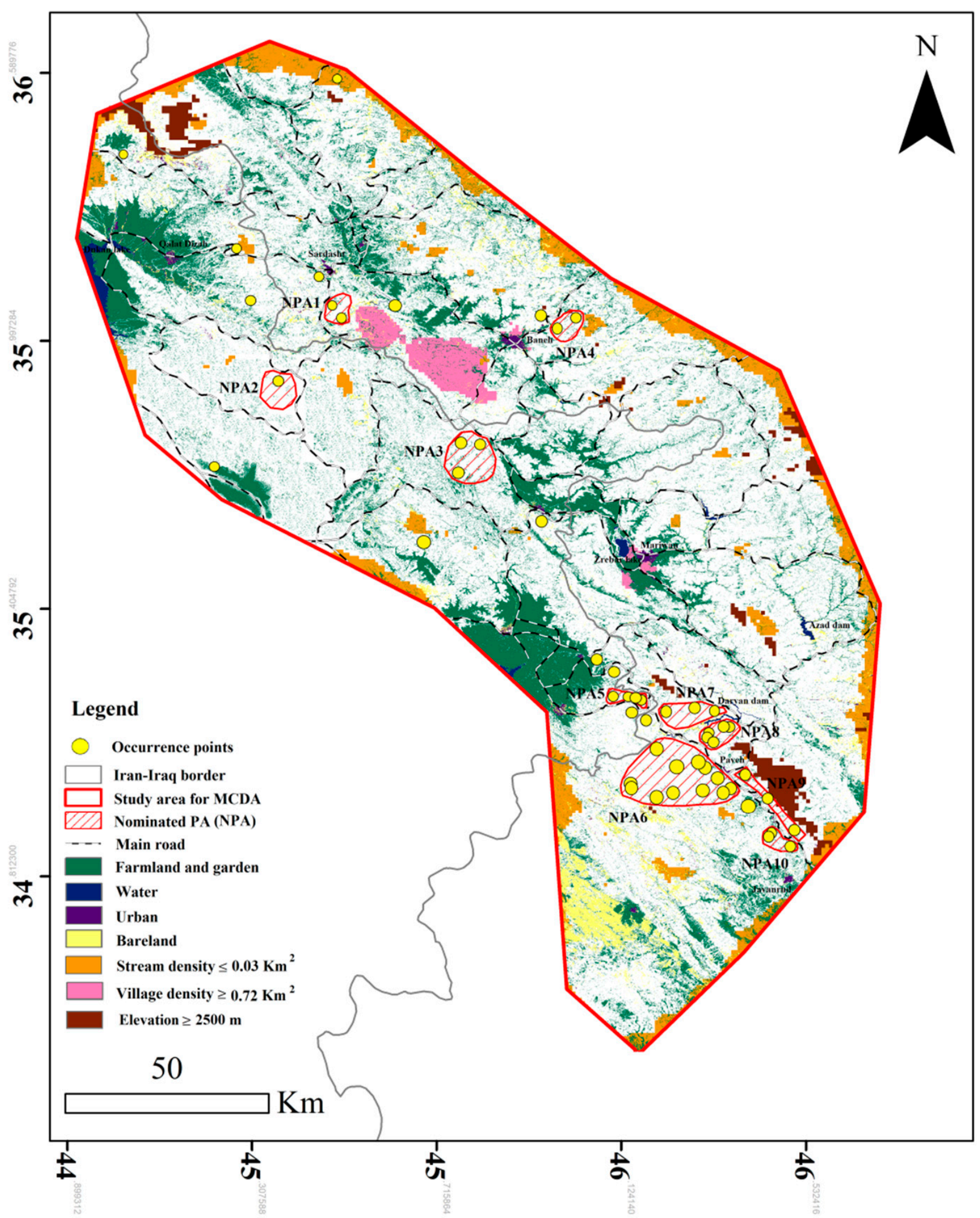

Figure 4. The exclusionary criteria within the study area including all main roads, all cities, high village density, all dams, the area with very low stream density, areas with poor vegetation, farmlands (concretely irrigated lands), and high elevations. NPA1-NPA10 (red polygons) represents the nominated areas for the protected area (NPAs). 


\subsubsection{Multi-Criteria Decision Analysis (MCDA)}

Non-exclusionary criteria including the number of newt localities, NPA connectivity, NPA shape (edge effect), NPA HS (\%): MRI-CGCM3: RCP85-2070, NPA HS (\%): CCSM4: RCP85-2070, NPA size; NPA HS (\%), MRI-CGCM3: RCP26-2070, NPA HS (\%): CCSM4: RCP26-2070, genetic diversity, distance to nearest PAs, villages density, distance to cities and distance to the main roads were used in the process of MCDA analysis.

NPA connectivity was measured using the nearest neighbor distance $(\mathrm{km})$ [83]. The size of the NPAs was obtained by measuring the area $\left(\mathrm{km}^{2}\right)$ in the GIS environment. NPA shape was calculated from the ratio of the boundary length of the NPAs divided by the area [84]:

$$
\text { NPAs shape }=\frac{\text { Boundary length }}{2 \sqrt{\pi \times \text { Area }}}
$$

Values near 1 have a circular shape and are relatively unfragmented and compact. The percent of habitat suitability in 2070 under optimistic (RCP26) and pessimistic (RCP85) scenarios from MRI-CGCM3 and CCSM4 models were used for MCDA analysis. To measure nucleotide diversity (Nd hereafter), sequences were obtained from GeneBank from three genes: NADH dehydrogenase subunit 4 (ND4), control region (D-loop), and NADH dehydrogenase subunit 2 (ND2), with accession numbers MN995079 to MN995069, MK098476 to MK098471, and MK035726 to MK035716, respectively. Distance to nearest PAs $(\mathrm{km})$; villages density; distance to cities $(\mathrm{km})$; distance to the main roads $(\mathrm{km})$ were also measured by GIS. Supplementary Materials Table S3 lists the non-exclusionary criteria as well as a short explanation of why they are important to choose. ArcMap v 10.6.1 was used for all the spatial analyses.

\subsubsection{Analytical Hierarchy Process (AHP)}

The analytical hierarchy process (AHP), as one of the MCDA methods, was used to obtain weights for non-exclusionary criteria [85]. A matrix cell was used to assess each pair-wise comparison according to the following values: 1 : relative to the column variable, the row variable is less important; 3 : relative to the column variable, the row variable is moderately more important; 5 : relative to the column variable, the row variable is equally more important; 7 : relative to the column variable, the row variable is strongly more important; 9: relative to the column variable, the row variable is extremely more important [64].

Finally, all NPAs (polygons) were evaluated using the Suitability Index (SI):

$$
\text { Suitability Index }=\sum_{i=1}^{n}(W i X i)
$$

The suitability index determines the suitability score for NPAs attained by $n$th alternative. The Wi is the weight of the factor calculated using the pair-wise comparison between various criteria and $\mathrm{Xi}$ is a value obtained from rating curves [64].

\section{Results}

\subsection{Ensemble Species Distribution Modelling (eSDM)}

Cohen's kappa (KAPPA), true skill statistic (TSS), and ROC curve (AUC), in all modelling techniques were high; however, Generalized Linear Models (GLMs), Generalized Boosted Models (GBMs), Random Forest (RF), Classification Tree Analysis (CTA), Artificial Neural Networks (ANNs), and Multivariate Adaptive Regression Splines (MARSs) were the best performing models, with AUC, TSS and KAPPA $>0.90$ (Table 1). In terms of mean relative importance (mean $\% \pm \mathrm{SD}$ ), the order of bioclimatic variables in eight $N$. derjugini distribution models, from high to low, is precipitation of driest month (BIO14: $24.47 \% \pm 2.29$ ), annual precipitation (BIO12: $22.73 \% \pm 2.00$ ), precipitation of wettest month (BIO13: 18.16\% \pm 3.38 ), annual mean temperature (BIO1:16.53\% \pm 6.33 ), temperature seasonality (BIO4: $10.21 \% \pm 1.62)$ and mean diurnal range $(\mathrm{BIO} 2: 7.88 \% \pm 0.38)$. 
Table 1. Mean $( \pm \mathrm{SD})$ true skill statistic (TSS), ROC curve (AUC), and Cohen's kappa (KAPPA) of eight used models projecting Neurergus derjugini distribution in western Iran and northeastern Iraq.

\begin{tabular}{ccccccccc}
\hline & GLM & GBM & RF & CTA & ANN & SRE & FDA & MARS \\
\hline KAPPA & $0.95 \pm 0.04$ & $0.96 \pm 0.04$ & $0.96 \pm 0.02$ & $0.91 \pm 0.05$ & $0.91 \pm 0.08$ & $0.79 \pm 0.03$ & $0.65 \pm 0.08$ & $0.95 \pm 0.04$ \\
\hline TSS & $0.95 \pm 0.04$ & $0.96 \pm 0.04$ & $0.96 \pm 0.02$ & $0.91 \pm 0.05$ & $0.91 \pm 0.08$ & $0.79 \pm 0.03$ & $0.65 \pm 0.08$ & $0.95 \pm 0.04$ \\
\hline AUC & $0.99 \pm 0.03$ & $1 \pm 0.00$ & $1 \pm 0.00$ & $0.96 \pm 0.02$ & $0.96 \pm 0.04$ & $0.90 \pm 0.008$ & $0.70 \pm 0.11$ & $0.98 \pm 0.01$ \\
\hline
\end{tabular}

Consensus models show $N$. derjugini responses to climate change. Based on the current $N$. derjugini distribution model, the northwest of Kermanshah, west of Kurdistan in western Iran, and northeast of Sulaymaniyah in northeastern Iraq have $75-100 \%$ habitat suitability. In comparison, southwest of west Azerbaijan in northwest Iran has 50-75\% habitat suitability (Figure 3). Species range change of $N$. derjugini in currently suitable habitats (gain/loss) by 2050 and 2070 under optimistic (RCP26) and pessimistic (RCP85) scenarios within the MRI-CGCM3 and CCSM4 models in western Iran and northeastern Iraq are given in Table 2 and shown in Supplementary Materials Figures S1 and S2. Based on the MRI-CGCM3 and CCSM4 models, habitat loss ranges from 29.62 to $38.15 \%$ and from 11.67 to $46.62 \%$ and habitat gain ranges from 1.15 to $0 \%$ and the range from 0.37 to $1.96 \%$ is for 2070, respectively (Table 2). As shown in Figures S1 and S2, in most scenarios, the margins of the distribution range of $N$. derjugini will be affected by future climate change. In particular, the loss of habitats at low altitudes and the gaining of new habitats at high altitudes were observed.

Table 2. Species range change of Neurergus derjugini in currently suitable habitats (gain/loss) by 2050 and 2070 under two optimistic (RCP26) and pessimistic (RCP85) scenarios within the MRI-CGCM3 and CCSM4 models in western Iran and northeastern Iraq.

\begin{tabular}{ccccc}
\hline Year/Scenario & \multicolumn{2}{c}{ Habitat Loss (\%) } & \multicolumn{2}{c}{ Habitat Gain (\%) } \\
\hline & MRI-CGCM3 & CCSM4 & MRI-CGCM3 & CCSM4 \\
\hline 2050 & & & & \\
RCP26 & 14.19 & 16.35 & 10.73 & 1.7 \\
RCP85 & 39.2 & 37.48 & 7.34 & \\
2070 & & & & 0.37 \\
RCP26 & 29.62 & 11.67 & 1.15 & 1.96 \\
RCP85 & 38.15 & 46.62 & 0 & \\
\hline
\end{tabular}

Habitats with 75 to $100 \%$ suitability are also more established at higher altitudes or latitude due to the future climate projections (Figure 5), especially in the CCSM4 model. Based on different classifications $(0-25 \%, 25-50 \%, 50-75 \%$, and $75-100 \%)$, the habitats area $\left(\mathrm{km}^{2}\right)$ of $N$. derjugini for the recent and future (2050 and 2070) climate projections under two optimistic (RCP 2.6) and pessimistic (RCP 8.5) scenarios within the MRI-CGCM3 and CCSM4 models are provided in Supplementary Materials Table S4. According to all scenarios and models, the area of habitats with $75-100 \%$ suitability will be decreased in 2050 and 2070 (Table S4). Habitats with 50-75\% suitability, on the other hand, will expand in size (Table S4).

\subsection{Siting Procedure}

All landscaping features that could damage the $N$. derjugini were excluded from the study area (Figure 4). These exclusionary criteria including all main roads, all cities, high village density $\left(\geq 0.72 \mathrm{~km}^{2}\right)$, all dams, the area with very low stream density $\left(\leq 0.03 \mathrm{~km}^{2}\right)$, areas with poor vegetation, farmlands (concretely irrigated lands), and elevations above $2500 \mathrm{~m}$ (Figure 2). As shown in Figure 4, the results of removing these harmful landscaping criteria from the study area are to create suitable locations where the $N$. derjugini may be safe. Then, within these areas, with the focus on areas contains N. derjugini habitats, 
10 polygons were created as NPAs so that they could accommodate the maximum number of $N$. derjugini habitats (Figure 4). After that, 13 non-exclusionary criteria were examined, including the number of newt localities, NPA connectivity, NPA shape (edge effect), NPA HS (\%): MRI-CGCM3: RCP85-2070 (Figure 5); NPA HS (\%): CCSM4: RCP85-2070 (Figure 5); NPA size; NPA HS (\%): MRI-CGCM3: RCP26-2070 (Figure 5); NPA HS (\%): CCSM4: RCP26-2070 (Figure 5), genetic diversity, distance to nearest PAs, villages density, distance to cities and distance to the main roads. Relationships between the quantities of the non-exclusionary criterion obtained from rating curves as values are shown in Supplementary Materials Table S5. The pair-wise comparison was used to the assigned weight of every non-exclusionary criterion (Supplementary Materials Table S6). The relative importance (weight) of 13 non-exclusionary criteria used to assess the final suitability score of each NPA is shown in Table S6. Finally, the suitability score was ranked for 10 different NPAs based on ratings and weights of the non-exclusionary criteria (Table 3). Among these NPAs, polygon no. 6 (NPA6: Figure 4) with scores of 0.94 can be the most suitable habitat to introduce as a PA for N. derjugini (Table 3).
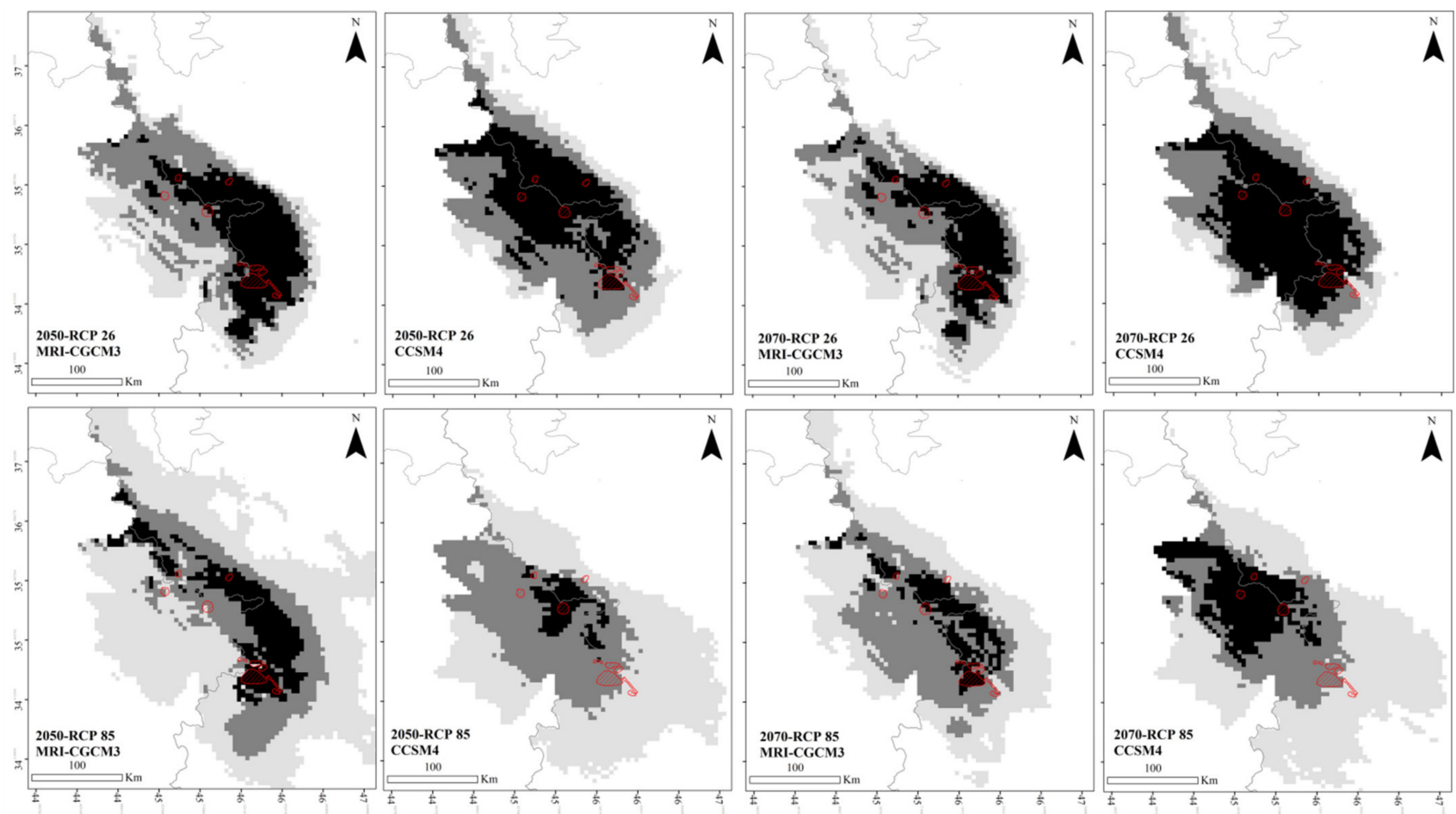

Figure 5. Future (2050 and 2070) habitat suitability (\%) for Neurergus derjugini under two optimistic (RCP26) and pessimistic (RCP85) scenarios within MRI-CGCM3 and CCSM4 models in western Iran and northeastern Iraq. The red polygons represent the nominated areas for the protected area (NPAs). 
Table 3. Suitability scores for 10 nominated protected areas (NPAs) evaluated based on eight exclusionary and 13 non-exclusionary criteria.

\begin{tabular}{|c|c|c|c|c|c|c|c|c|c|c|c|}
\hline & Criterion & NPA 1 & NPA 2 & NPA 3 & NPA 4 & NPA 5 & NPA 6 & NPA 7 & NPA 8 & NPA 9 & NPA 10 \\
\hline 1 & Number of newt localities & 0.03 & 0.01 & 0.05 & 0.03 & 0.06 & 0.17 & 0.05 & 0.08 & 0.05 & 0.05 \\
\hline 2 & NPA HS (\%): MRI-CGCM3: RCP85-2070 & 0.15 & 0.10 & 0.12 & 0.08 & 0.15 & 0.15 & 0.14 & 0.10 & 0.10 & 0.10 \\
\hline 3 & NPA HS (\%): CCSM4: RCP85-2070 & 0.12 & 0.12 & 0.12 & 0.08 & 0.08 & 0.08 & 0.08 & 0.08 & 0.04 & 0.04 \\
\hline 5 & NPA size $\left(\mathrm{km}^{2}\right)$ & 0.02 & 0.05 & 0.08 & 0.02 & 0.02 & 0.11 & 0.05 & 0.02 & 0.02 & 0.02 \\
\hline 6 & NPA connectivity: nearest neighbor distance $(\mathrm{km})$ & 0.02 & 0.02 & 0.06 & 0.04 & 0.08 & 0.08 & 0.08 & 0.08 & 0.06 & 0.06 \\
\hline 7 & NPA HS (\%): MRI-CGCM3: RCP26-2070 & 0.07 & 0.04 & 0.05 & 0.07 & 0.06 & 0.07 & 0.07 & 0.07 & 0.07 & 0.07 \\
\hline 8 & NPA HS (\%): CCSM4: RCP26-2070 & 0.06 & 0.06 & 0.06 & 0.05 & 0.06 & 0.06 & 0.06 & 0.06 & 0.04 & 0.04 \\
\hline 10 & Distance to nearest PAs $(\mathrm{km})$ & 0.03 & 0.02 & 0.01 & 0.01 & 0.04 & 0.04 & 0.04 & 0.04 & 0.03 & 0.03 \\
\hline 11 & Village density $\left(\mathrm{km}^{2}\right)$ & 0.01 & 0.03 & 0.02 & 0.02 & 0.03 & 0.02 & 0.01 & 0.02 & 0.02 & 0.02 \\
\hline 12 & Distance to cities & 0.01 & 0.02 & 0.015 & 0.01 & 0.015 & 0.01 & 0.015 & 0.01 & 0.01 & 0.01 \\
\hline \multirow[t]{2}{*}{13} & Distance to the main road & 0.002 & 0.005 & 0.005 & 0.002 & 0 & 0.01 & 0.005 & 0.005 & 0.002 & 0.002 \\
\hline & Suitability score & 0.65 & 0.60 & 0.72 & 0.55 & 0.70 & 0.94 & 0.71 & 0.70 & 0.49 & 0.55 \\
\hline
\end{tabular}




\section{Discussion}

Protected areas (PAs), as one of the leading conservation tools for biodiversity, are mainly associated with potential failure to protect species against climate and landscape change [19,86-96]. While some studies have shown that PAs remained suitable climates, facilitated the range expansion and colonization of species, and decreased historical habitat loss [89,97-100]. In this study, for the first time, a PA was designed for critically endangered yellow-spotted $N$. derjugini by integrating eSDM, GIS, and MCDA methods to map and exclude the impact of climate and landscape change. The SDM, by predicting the range of species distribution based on the present condition and the future projection, allows calculating the gain or loss of habitats [101]. The GIS-based MCDA approach allows land management by decision-makers the a landscape scale based on a set of criteria, indicators, and preferences for the area [102]. The methodology proposed in this study can easily be used as an extensible model to introduce a new PA for other animal and plant species and it has already proved to be a powerful tool in natural system development and conservation. This research, on the other hand, can be generalized to other conservation efforts, such as identifying a suitable reintroduction site.

\subsection{Climate Change}

Recent findings highlighted that many amphibians, including salamanders, may face threats as a result of future climatic and landscape change [103-114]. Based on modelling results, most of Iran will be exposed to drought within the next 30 years if global warming continues [115-117], and this climate change will have an effect on the region's small native amphibians [95]. According to projections by the Intergovernmental Panel on Climate Change (IPCC) for 2100, based on the assumption of continued increase in greenhouse gas emissions in the twenty-first century, Iran may be exposed to temperatures of 1.5 to $4.5^{\circ} \mathrm{C}$ under the pessimistic scenarios [118]. In a study by Daneshvar et al. [119], the temperature increase is predicted to range from 1.12 to $7.87^{\circ} \mathrm{C}$ by 2100 . Studies on the future climatic conditions in Iran show an unpleasant picture, including repeated periods of extreme humidity and drought throughout the country, particularly along the Zagros mountains $[115,118]$. In the study by Vaghefi, Keykhai, Jahanbakhshi, Sheikholeslami, Ahmadi, Yang and Abbaspour [115], a temperature increase of 1.1 to $2.75{ }^{\circ} \mathrm{C}$ has been reported in Iran under four climatic scenarios (RCP2.6, RCP4.5, RCP6.0, RCP8.5), with a temperature increase of 2.25 to $2.5^{\circ} \mathrm{C}$ for Zagros under the pessimistic scenario. The analysis of rainfall indicates that the humid regions of the country are becoming wetter, while the arid regions are becoming drier, so rainfall in some areas of the Zagros, especially in the southwestern parts, is expected to increase by 25 to $50 \mathrm{~mm}[115,120]$.

The eSDM projections of this study revealed that future climate change will have a greater impact on the edges of species distribution range's (Figures S1 and S2). According to the MRI-CGCM3 model, in 2050, under both optimistic (RCP26) and pessimistic (RCP85) scenarios, habitats suitable for the $N$. derjugini will be more lost at low altitudes, but new habitats will be gained at higher altitudes, especially on the southern and southeastern edges of the distribution range (Figure S1A,C), whereas in 2070, under both scenarios, especially the pessimistic one (RCP85), the edges of the species distribution range will be lost either at low or high altitudes, especially in the northeastern part (Figure S1B,D). However, under an optimistic (RCP26) scenario, the new habitat would be gained in the southern part of the distribution range at higher altitudes (Figure S1B). Based on the CCSM4 model, both in 2050 and in 2070, the edges of the distribution area (except for the northwest of the distribution area) also suffered a loss of habitats (Figure S2). At higher altitudes or latitudes, new habitats were gained in the northwest and particularly in the northeast of the distribution range in this model (Figure S2). Compared to closely related mountain newts, $N$. kaiseri, it seems that $N$. derjugini is more resistant to future climate change. Ashrafzadeh, Naghipour, Haidarian, Kusza and Pilliod [73] found that suitable habitats for $N$. kaiseri under the influence of future climate change will be reduced by $56 \%$ 
and $96 \%$ by 2050 and 2070 , respectively. It was also predicted that the species would be shifted to higher altitudes [73].

Low dispersal ability in some species, especially $N$. derjugini, with an average migration distance of $49.19 \pm 71.75 \mathrm{~m}$, see [68], may increase the probability of local adaptation and decrease their distribution range to track favorable climate conditions [121-124]. The ability of these species to survive in highly variable climates usually depends on their ability to find climate refugia that are relatively buffered from contemporary climate change over time $[125,126]$. The results of this study are consistent with previous findings of $N$. derjugini, which suggest that glacial and interglacial cycles affect the species' distribution pattern $[127,128]$. Climate conditions seem to have been more favorable for the $N$. derjugini during the Last Glacial Maximum (LGM) in a broader area than today [127]. In contrast, the distribution range of $N$. derjugini has retreated during the Holocene to current climate conditions [127]. According to the present result, this decline will continue in the future (2050 and 2070). Cold-adapted species usually follow this pattern, expanding their distribution during the last glacial period and contracting it during post-glacial warming [127,129-131].

In a study conducted by Malekoutian, Sharifi and Vaissi [128], three glacial refugia in the southern, central, and northern parts of the N. derjugini distribution range were shown using genetic data. Additionally, in the study conducted by Afroosheh, Rödder, Mikulicek, Akmali, Vaissi, Fleck, Schneider and Sharifi [127], the existence of glacial refugia in the central and southern parts of the distribution range was predicted by SDM. The present study also showed that due to potential future climate change, the range of species distribution would be maintained in the southern, central, and northern parts of the species distribution (except for the margins). Therefore, the results of this study and previous studies $[127,128]$ confirm that the Zagros mountains may act as climatic refugia for $N$. derjugini. According to recent studies, identifying and subsequently protecting climate refugia, where climates are likely to remain suitable, may be a solution for species conservation [132-134].

\subsection{Landscape Change}

In addition to climate change, the negative impact of human activities in and outside PAs, such as agricultural activities, urbanization, roads construction, and industrial and mining activities, as well as negative effects of noise related to these activities on the performance and protection of these areas is well known and has been the subject of much research [135-138]. In Iran, insufficient management of natural resources, pollution, unchecked urbanization, dam construction, draining of wetlands, deforestation, excessive irrigation, poaching, and lack of scientific and financial support are a severe concern for the loss of biodiversity as a result of landscape changes [139-142]. These negative changes have been increasing rapidly in recent decades $[143,144]$ and may have an effect on the natural habitat of fauna and flora, animal and plant species, and presentation of ecosystem services $[145,146]$.

The oak forests of the Zagros in western Iran have been used for agricultural activities, grazing, purposes and livestock breeding since about 5 millennia years ago $[147,148]$. Integration of rapid development and urban expansion with disturbance and traditional livestock grazing as well as severe drought, especially in recent years, are the major issues that have led to changes in the vertical structure or deforestation, configuration, and composition of Zagros mountains forests [149]. In this study, it was not possible to remove some degree of human resources such as some villages, dry farmland, and orchards due to their recognition as enclaves for places with decades or centuries of human inhabitation. However, this study tried to minimize and remove all factors that may damage and decline amphibians inside the introduced PA (Tables S2 and S3). This policy of incorporating PAs in the broader cultural landscape has recently been seen as a vital issue in both conservation and development [150]. However, landscape change must be monitored from the viewpoint of the effectiveness of mixed-use PAs over time [25]. 


\section{Conclusions}

The current study developed a practical approach to integrating eSDM, GISs, and MCDA in order to provide a set of ranked areas by tracking and excluding the effect of climate and landscape changes, which helped managers and other stakeholders in creating PAs. However, more detailed studies on actually selected sites may be needed and can be carried out by field experts. This study can also act as a model for other species that require the establishment of PAs or reintroduction sites.

Supplementary Materials: The following are available at https://www.mdpi.com/article/10.3 390/su13105645/s1; Table S1. The data set used in this study for ensemble species distribution modelling. The information includes the name of localities, geographical coordinates and origin; Table S2. A brief description of the exclusionary criteria used in siting procedure; Table S3. A brief description of the non-exclusionary criteria used in siting procedure; Table S4. Habitat areas (Km2) of the Yellow-spotted mountain newt, Neurergus derjugini, according to different classifications and recent and future (2050 and 2070) periods under two optimistic (RCP 2.6) and pessimistic (RCP 8.5) scenarios within the MRI-CGCM3 and CCSM4 models in western Iran and northeastern Iraq; Table S5. The no-exclusionary criteria and their relative suitability obtained from 13 rating curves; Table S6. Weight of 13 non-exclusionary criteria result of the pair-wise comparison; Figure S1. Species range change of Neurergus derjugini in currently suitable habitats (gain/loss) by 2050 and 2070 under two optimistic (RCP26) and pessimistic (RCP85) scenarios within the MRI-CGCM3 model in western Iran and northeastern Iraq; Figure S2. Species range change of Neurergus derjugini in currently suitable habitats (gain/loss) by 2050 and 2070 under two optimistic (RCP26) and pessimistic (RCP85) scenarios within the CCSM4 model in western Iran and northeastern Iraq; Scripts S1. The scripts used in the biomod2 settings.

Funding: This research received no external funding.

Institutional Review Board Statement: Not applicable.

Informed Consent Statement: Not applicable.

Data Availability Statement: Bioclimatic variables and digital elevation model (DEM), with a $30 \mathrm{~s}$ spatial resolution $(\sim 1 \mathrm{~km})$ are available in WorldClim (https://www.worldclim.org; accessed on 5 March 2021). The Iran land cover map with a spatial resolution of $10 \mathrm{~m}$ is available in Google Earth Engine (GEE) (https:/ / earthengine.google.com; accessed on 5 March 2021) [81]. The Iran main roads, villages and protected areas with a $30 \mathrm{~m}$ resolution are available in the Iranian Forest, Rangeland, and Watershed Management Organization [82]. Iraq land cover and the main rod with a 30 s spatial resolution $(\sim 1 \mathrm{~km})$ are available in the United States Geological Survey (USGS) and Diva-GIS (http: / / www.diva-gis.org; accessed on 5 March 2021). The NADH dehydrogenase subunit 4 (ND4), control region (D-loop), and NADH dehydrogenase subunit 2 (ND2) genes are available in GeneBank with accession numbers MN995079 to MN995069, MK098476 to MK098471, and MK035726 to MK035716, respectively. Additionally, all layers and relevant files are available upon request to s.vaissi@razi.ac.ir.

Conflicts of Interest: The author declares no conflict of interest.

\section{References}

1. Collins, J.P.; Storfer, A. Global amphibian declines: Sorting the hypotheses. Divers. Distrib. 2003, 9, 89-98. [CrossRef]

2. Grant, E.H.C.; Miller, D.A.; Muths, E. A Synthesis of evidence of drivers of amphibian declines. Herpetologica 2020, 76, 101-107. [CrossRef]

3. Velasco, J.A.; Estrada, F.; Calderón-Bustamante, O.; Swingedouw, D.; Ureta, C.; Gay, C.; Defrance, D. Synergistic impacts of global warming and thermohaline circulation collapse on amphibians. Commun. Biol. 2021, 4, 1-7. [CrossRef] [PubMed]

4. Davidson, C.; Shaffer, H.B.; Jennings, M.R. Spatial tests of the pesticide drift, habitat destruction, UV-B, and climate-change hypotheses for California amphibian declines. Conserv. Biol. 2002, 16, 1588-1601. [CrossRef]

5. Egea-Serrano, A.; Relyea, R.A.; Tejedo, M.; Torralva, M. Understanding of the impact of chemicals on amphibians: A meta-analytic review. Ecol. Evol. 2012, 2, 1382-1397. [CrossRef]

6. Blaustein, A.R.; Romansic, J.M.; Kiesecker, J.M.; Hatch, A.C. Ultraviolet radiation, toxic chemicals and amphibian population declines. Divers. Distrib. 2003, 9, 123-140. [CrossRef]

7. Duenas, M.-A.; Hemming, D.J.; Roberts, A.; Diaz-Soltero, H. The threat of invasive species to IUCN-listed critically endangered species: A systematic review. Glob. Ecol. Conserv. 2021, e01476. [CrossRef] 
8. Jensen, J.B.; Camp, C.D. Human exploitation of amphibians. In Amphibian Conservation; Semlitsch, R.D., Ed.; Smithsonian Books: Washington, DC, USA, 2003.

9. Rollins-Smith, L.A. Global amphibian declines, disease, and the ongoing battle between Batrachochytrium fungi and the immune system. Herpetologica 2020, 76, 178-188. [CrossRef]

10. Rebouças, R.; Dos Santos, M.M.; da Silva Martins, A.G.; Domingos, A.H.R.; Santos, I.; Toledo, L.F. Warming drives cryptic declines of amphibians in eastern Brazil. Biol. Conserv. 2021, 256, 109035. [CrossRef]

11. Grant, E.; Zipkin, E.; Nichols, J.; Campbell, J. A Strategy for monitoring and managing declines in an amphibian community. Conserv. Biol. J. Soc. Conserv. Biol. 2013, 27, 1245-1253. [CrossRef]

12. Nori, J.; Lemes, P.; Urbina-Cardona, N.; Baldo, D.; Lescano, J.; Loyola, R. Amphibian conservation, land-use changes and protected areas: A global overview. Biol. Conserv. 2015, 191, 374. [CrossRef]

13. Brito, D. Amphibian conservation: Are we on the right track? Biol. Conserv. 2008, 141, 2912-2917. [CrossRef]

14. Schulze, K.; Knights, K.; Coad, L.; Geldmann, J.; Leverington, F.; Eassom, A.; Marr, M.; Butchart, S.H.; Hockings, M.; Burgess, N.D. An assessment of threats to terrestrial protected areas. Conserv. Lett. 2018, 11, e12435. [CrossRef]

15. Hole, D.G.; Willis, S.G.; Pain, D.J.; Fishpool, L.D.; Butchart, S.H.; Collingham, Y.C.; Rahbek, C.; Huntley, B. Projected impacts of climate change on a continent-wide protected area network. Ecol. Lett. 2009, 12, 420-431. [CrossRef]

16. Hoffmann, S.; Beierkuhnlein, C. Climate change exposure and vulnerability of the global protected area estate from an international perspective. Divers. Distrib. 2020, 26, 1496-1509. [CrossRef]

17. Lawler, J.J.; Rinnan, D.S.; Michalak, J.L.; Withey, J.C.; Randels, C.R.; Possingham, H.P. Planning for climate change through additions to a national protected area network: Implications for cost and configuration. Philos. Trans. R. Soc. B 2020, 375, 20190117. [CrossRef]

18. Roberts, C.M.; O'Leary, B.C.; Hawkins, J.P. Climate change mitigation and nature conservation both require higher protected area targets. Philos. Trans. R. Soc. B 2020, 375, 20190121. [CrossRef] [PubMed]

19. Lemieux, C.J.; Scott, D.J. Changing climate, challenging choices: Identifying and evaluating climate change adaptation options for protected areas management in Ontario, Canada. Environ. Manag. 2011, 48, 675. [CrossRef] [PubMed]

20. Zomer, R.J.; Xu, J.; Wang, M.; Trabucco, A.; Li, Z. Projected impact of climate change on the effectiveness of the existing protected area network for biodiversity conservation within Yunnan Province, China. Biol. Conserv. 2015, 184, 335-345. [CrossRef]

21. Mairota, P.; Cafarelli, B.; Boccaccio, L.; Leronni, V.; Labadessa, R.; Kosmidou, V.; Nagendra, H. Using landscape structure to develop quantitative baselines for protected area monitoring. Ecol. Indic. 2013, 33, 82-95. [CrossRef]

22. Kroner, R.E.G.; Krithivasan, R.; Mascia, M.B. Effects of protected area downsizing on habitat fragmentation in Yosemite National Park (USA), 1864-2014. Ecol. Soc. 2016, 21. [CrossRef]

23. Dimobe, K.; Goetze, D.; Ouédraogo, A.; Forkuor, G.; Wala, K.; Porembski, S.; Thiombiano, A. Spatio-temporal dynamics in land use and habitat fragmentation within a protected area dedicated to tourism in a Sudanian savanna of West Africa. J. Landsc. Ecol. 2017, 10, 75-95. [CrossRef]

24. Tomaselli, V.; Tenerelli, P.; Sciandrello, S. Mapping and quantifying habitat fragmentation in small coastal areas: A case study of three protected wetlands in Apulia (Italy). Environ. Monit. Assess. 2012, 184, 693-713. [CrossRef]

25. López, S.; López-Sandoval, M.F.; Gerique, A.; Salazar, J. Landscape change in Southern Ecuador: An indicator-based and multi-temporal evaluation of land use and land cover in a mixed-use protected area. Ecol. Indic. 2020, 115, 106357. [CrossRef]

26. Rafaai, N.H.; Abdullah, S.A.; Reza, M.I.H. Identifying factors and predicting the future land-use change of protected area in the agricultural landscape of Malaysian peninsula for conservation planning. Remote Sens. Appl. Soc. Environ. 2020, 18, 100298. [CrossRef]

27. Bai, X.; Du, P.; Guo, S.; Zhang, P.; Lin, C.; Tang, P.; Zhang, C. Monitoring land cover change and disturbance of the mount wutai world cultural landscape heritage protected area, based on remote Sensing time-Series images from 1987 to 2018 . Remote Sens. 2019, 11, 1332. [CrossRef]

28. Xie, Z.; Liu, J.; Ma, Z.; Duan, X.; Cui, Y. Effect of surrounding land-use change on the wetland landscape pattern of a natural protected area in Tianjin, China. Int. J. Sustain. Dev. World Ecol. 2012, 19, 16-24. [CrossRef]

29. Schmidt, C.; Garroway, C.J. Inconsistent effects of urbanization on amphibian genetic diversity. BioRxiv 2020. [CrossRef]

30. Lin, P.; Yang, L.; Zhao, S. Urbanization effects on Chinese mammal and amphibian richness: A multi-scale study using the urban-rural gradient approach. Environ. Res. Commun. 2020, 2, 125002. [CrossRef]

31. Agostini, M.G.; Roesler, I.; Bonetto, C.; Ronco, A.E.; Bilenca, D. Pesticides in the real world: The consequences of GMO-based intensive agriculture on native amphibians. Biol. Conserv. 2020, 241, 108355. [CrossRef]

32. Li, B.; Zhang, W.; Wang, Z.; Xie, H.; Yuan, X.; Pei, E.; Wang, T. Effects of landscape heterogeneity and breeding habitat diversity on rice frog abundance and body condition in agricultural landscapes of Yangtze River Delta, China. Curr. Zool. 2020, 66, 615-623. [CrossRef] [PubMed]

33. Sutherland, R.W.; Dunning, P.R.; Baker, W.M. Amphibian encounter rates on roads with different amounts of traffic and urbanization. Conserv. Biol. 2010, 24, 1626-1635. [CrossRef] [PubMed]

34. Elzanowski, A.; Ciesiołkiewicz, J.; Kaczor, M.; Radwańska, J.; Urban, R. Amphibian road mortality in Europe: A meta-analysis with new data from Poland. Eur. J. Wildl. Res. 2009, 55, 33-43. [CrossRef]

35. Cushman, S.A. Effects of habitat loss and fragmentation on amphibians: A review and prospectus. Biol. Conserv. 2006, 128, 231-240. [CrossRef] 
36. Dixo, M.; Metzger, J.P.; Morgante, J.S.; Zamudio, K.R. Habitat fragmentation reduces genetic diversity and connectivity among toad populations in the Brazilian Atlantic Coastal Forest. Biol. Conserv. 2009, 142, 1560-1569. [CrossRef]

37. Allentoft, M.E.; O’Brien, J. Global amphibian declines, loss of genetic diversity and fitness: A review. Diversity 2010, 2, 47-71. [CrossRef]

38. IPCC. Climate Change 2007-The Physical Science Basis; Cambridge University Press: Cambridge, UK, 2007.

39. Wake, D.; Vredenburg, V. Are we in the midst of the sixth mass extinction? A view from the world of amphibians. Proc. Natl. Acad. Sci. USA 2008, 105, 11466-11473. [CrossRef]

40. Reading, C. Linking global warming to amphibian declines through its effects on female body condition and survivorship. Oecologia 2007, 151, 125-131. [CrossRef] [PubMed]

41. McMenamin, S.K.; Hadly, E.A.; Wright, C.K. Climatic change and wetland desiccation cause amphibian decline in Yellowstone National Park. Proc. Natl. Acad. Sci. USA 2008, 105, 16988-16993. [CrossRef]

42. Duan, R.-Y.; Kong, X.; Huang, M.-Y.; Varela, S.; Ji, X. The potential effects of climate change on amphibian distribution, range fragmentation and turnover in China. PeerJ 2016, 4, e2185. [CrossRef]

43. Raxworthy, C.; Pearson, R.; Rabibisoa, N.; Rakotondrazafy, A.; Ramanamanjato, J.; Raselimanana, A.P.; Wu, S.-H.; Nussbaum, R.; Stone, D. Extinction vulnerability of tropical montane endemism from warming and upslope displacement: A preliminary appraisal for the highest massif in Madagascar. Glob. Chang. Biol. 2008, 14, 1703-1720. [CrossRef]

44. Smeraldo, S.; Bosso, L.; Salinas-Ramos, V.B.; Ancillotto, L.; Sánchez-Cordero, V.; Gazaryan, S.; Russo, D. Generalists yet different: Distributional responses to climate change may vary in opportunistic bat species sharing similar ecological traits. Mammal. Rev. 2021. [CrossRef]

45. Zu, K.; Wang, Z.; Zhu, X.; Lenoir, J.; Shrestha, N.; Lyu, T.; Luo, A.; Li, Y.; Ji, C.; Peng, S. Upward shift and elevational range contractions of subtropical mountain plants in response to climate change. Sci. Total Environ. 2021, 146896. [CrossRef] [PubMed]

46. Nesterov, P. Tri novych chvostatych amfibii is kurdistana. Annu. Du Musée Zool. De L'académie Des. Sci. 1916, 21, 1-30.

47. Schmidtler, J.; Schmidtler, J. Untersuchungen an westpersischen Bergbachmolchen der Gattung Neurergus (Caudata, Salamandridae). Salamandra 1975, 11, 84-98.

48. Sharifi, M.; Assadian, S. Distribution and conservation status of Neurergus microspilotus (Caudata: Salamandridae) in western Iran. Asiat. Herpetol. Res. 2004, 10, 224-229.

49. Najafimajd, E.; Kaya, U. A newly found locality for the critically endangered Yellow Spotted Newt, Neurergus microspilotus (Nesterov, 1917) nourishes hope for its conservation: (Salamandridae: Caudata). Zool. Middle East. 2010, 51, 51-56. [CrossRef]

50. Schneider, C.; Schneider, W. Die Bergbachmolche der Gattung Neurergus im Irak. Herpetozoa 2011, 23, 3-20.

51. Naderi, B. Ecological studies (distribution, conservation status, courtship and foraging behavior) in two species of Neurergus. Master's Thesis, Razi University, Kermanshah, Iran, 2012; 74p.

52. Al-Sheikhly, O.; Iyad, A.; Rastegar-Pouyani, N.; Browne, R. New localities of the Kurdistan newt Neurergus microspilotus and Lake Urmia newt Neurergus crocatus (Caudata: Salamandridae) in Iraq. Amphib. Reptile Conserv. 2013, 6, $42-49$.

53. Rastegar-Pouyani, N.; Mirani, R.; Bahmani, Z.; Karamiani, R.; Takesh, M.; Browne, R. Conservation status of the Kurdistan newt Neurergus microspilotus in Kermanshah and Kurdistan provinces, Iran. Amphib. Reptile Conserv. 2015, 9, 36-41.

54. Zarei, F.; Hosseini, S.N.; Amini, S.S.; Pezeshk, J.; Soofi, M.; Esmaeili, H.R. A new locality of Kurdistan newt, Neurergus derjugini derjugini (Nesterov, 1916) represents a large population in Iran: Implication for conservation. Herpetol. Notes 2017, 10, 611-614.

55. Afroosheh, M.; Akmali, V.; Esmaili, S.; Sharifi, M. Distribution and abundance of the endangered yellow spotted mountain newt Neurergus microspilotus (Caudata: Salamandridae) in western Iran. Herpetol. Conserv. Biol. 2016, 11, 52-60.

56. Mawloudi, S.; Rastegar-Pouyani, N.; Rastegar-Pouyani, E. Four new localities for the Eendangered Kurdistan newt Neurergus derjugini (Nesterov, 1916) (Amphibia: Salamandridae) in Kermanshah province, western Iran. Russ. J. Herpetol. 2019, 26, 235-241. [CrossRef]

57. Sharifi, M.; Shafiei Bafti, S.; Papenfuss, T.; Anderson, S.; Kuzmin, S.; Rastegar-Pouyani, N. Neurergus microspilotus (errata version published in 2016). IUCN Red List Threat. Species 2009, e.T59451A8664238. [CrossRef]

58. Rastegar-Pouyani, N.; Takesh, M.; Fattahi, A.; Sadeghi, M.; Khorshidi, F.; Browne, R. Ecology of Kurdistan newt (Neurergus microspilotus: Salamandridae): Population and conservation with an appraisal of the potential impact of urbanization. Amphib. Reptile Conserv. 2013, 6, 30-35.

59. Rastegar-Pouyani, N. Conservation and Distribution of Neurergus Microspilotus (Caudata: Salamandridae) in the Zagros Mountains, Kermanshah Province, Western Iran. Herpetologia Bonnensis II. In Proceedings of the 13th Congress of the Societas Europaea Herpetologica, Societas Europaea Herpetologica, Bonn, Germany, 27 September-2 October 2005; pp. 115-116.

60. Phua, M.-H.; Minowa, M. A GIS-based multi-criteria decision making approach to forest conservation planning at a landscape scale: A case study in the Kinabalu Area, Sabah, Malaysia. Landsc. Urban. Plan. 2005, 71, 207-222. [CrossRef]

61. Rodríguez, J.P.; Brotons, L.; Bustamante, J.; Seoane, J. The application of predictive modelling of species distribution to biodiversity conservation. Divers. Distrib. 2007, 13, 243-251. [CrossRef]

62. Wilson, C.D.; Roberts, D.; Reid, N. Applying species distribution modelling to identify areas of high conservation value for endangered species: A case study using Margaritifera margaritifera (L.). Biol. Conserv. 2011, 144, 821-829. [CrossRef]

63. Villero, D.; Pla, M.; Camps, D.; Ruiz-Olmo, J.; Brotons, L. Integrating species distribution modelling into decision-making to inform conservation actions. Biodivers. Conserv. 2017, 26, 251-271. [CrossRef] 
64. Vaissi, S.; Sharifi, M. Integrating multi-criteria decision analysis with a GIS-based siting procedure to select a protected area for the Kaiser's mountain newt, Neurergus kaiseri (Caudata: Salamandridae). Glob. Ecol. Conserv. 2019, 20, e00738. [CrossRef]

65. Rodriguez-Merino, A.; Garcia-Murillo, P.; Fernandez-Zamudio, R. Combining multicriteria decision analysis and GIS to assess vulnerability within a protected area: An objective methodology for managing complex and fragile systems. Ecol. Indic. 2020, 108, 105738. [CrossRef]

66. Préau, C.; Isselin-Nondedeu, F.; Sellier, Y.; Bertrand, R.; Grandjean, F. Predicting suitable habitats of four range margin amphibians under climate and land-use changes in southwestern France. Reg. Environ. Chang. 2019, 19, 27-38. [CrossRef]

67. Yang, Y.; Ren, G.; Li, W.; Huang, Z.; Lin, A.K.; Garber, P.A.; Ma, C.; Yi, S.; Momberg, F.; Gao, Y. Identifying transboundary conservation priorities in a biodiversity hotspot of China and Myanmar: Implications for data poor mountainous regions. Glob. Ecol. Conserv. 2019, 20, e00732. [CrossRef]

68. Afroosheh, M.; Sharifi, M. Studying migratory activity and home range of adult Neurergus microspilotus (NESTEROV, 1916) in the Kavat Stream, western Iran, using photographic identification (Caudata: Salamandridae). Herpetozoa 2014, $27,77-82$.

69. Gent, P.R.; Danabasoglu, G.; Donner, L.J.; Holland, M.M.; Hunke, E.C.; Jayne, S.R.; Lawrence, D.M.; Neale, R.B.; Rasch, P.J.; Vertenstein, M. The community climate system model version 4. J. Clim. 2011, 24, 4973-4991. [CrossRef]

70. Yukimoto, S.; Adachi, Y.; Hosaka, M.; Sakami, T.; Yoshimura, H.; Hirabara, M.; Tanaka, T.Y.; Shindo, E.; Tsujino, H.; Deushi, M.; et al. A new global climate model of the Meteorological Research Institute: MRI-CGCM3-model description and basic performance-. J. Meteorol. Soc. Jpn. Ser. II 2012, 90A, 23-64.

71. Mohammadi, S.; Ebrahimi, E.; Moghadam, M.S.; Bosso, L. Modelling current and future potential distributions of two desert jerboas under climate change in Iran. Ecol. Inform. 2019, 52, 7-13. [CrossRef]

72. Shajari, A.; Sanjerehei, M.M. Modeling the distribution of urolithiasis prevalence under projected climate change in Iran. Urolithiasis 2015, 43, 339-347. [CrossRef]

73. Ashrafzadeh, M.R.; Naghipour, A.A.; Haidarian, M.; Kusza, S.; Pilliod, D.S. Effects of climate change on habitat and connectivity for populations of a vulnerable, endemic salamander in Iran. Glob. Ecol. Conserv. 2019, 19, e00637. [CrossRef]

74. Almasieh, K.; Zoratipour, A.; Negaresh, K.; Hasanzadeh, K.D. Habitat quality modelling and effect of climate change on the distribution of Centaurea pabotii in Iran. Span. J. Agric. Res. 2018, 16, 1-9. [CrossRef]

75. Abbasian, M.; Moghim, S.; Abrishamchi, A. Performance of the general circulation models in simulating temperature and precipitation over Iran. Theor. Appl. Climatol. 2019, 135, 1465-1483. [CrossRef]

76. Thuiller, W.; Georges, D.; Engler, R.; Breiner, F.; Georges, M.D.; Thuiller, C.W. Package 'biomod2'. Species Distribution Modeling within an Ensemble Forecasting Framework Version 3.3-7. 2016. Available online: https://cran.microsoft.com/snapshot/2016-08-05 /web/packages/biomod2/index.html (accessed on 5 March 2021).

77. Hamid, M.; Khuroo, A.A.; Charles, B.; Ahmad, R.; Singh, C.; Aravind, N. Impact of climate change on the distribution range and niche dynamics of Himalayan birch, a typical treeline species in Himalayas. Biodivers. Conserv. 2019, 28, 2345-2370. [CrossRef]

78. Iturbide, M.; Bedia, J.; Herrera, S.; del Hierro, O.; Pinto, M.; Gutiérrez, J.M. A framework for species distribution modelling with improved pseudo-absence generation. Ecol. Model. 2015, 312, 166-174. [CrossRef]

79. Guisan, A.; Thuiller, W.; Zimmermann, N.E. Habitat Suitability and Distribution Models: With Applications in R; Cambridge University Press: Cambridge, UK, 2017.

80. Zhang, P.; Grenouillet, G.; Dong, X.; Zheng, Y.; Lek, S.; Chang, J. Capturing response differences of species distribution to climate and human pressures by incorporating local adaptation: Implications for the conservation of a critically endangered species. J. Environ. Manag. 2021, 284, 111998. [CrossRef]

81. Ghorbanian, A.; Kakooei, M.; Amani, M.; Mahdavi, S.; Mohammadzadeh, A.; Hasanlou, M. Improved land cover map of Iran using Sentinel imagery within Google Earth Engine and a novel automatic workflow for land cover classification using migrated training samples. ISPRS J. Photogramm. Remote Sens. 2020, 167, 276-288. [CrossRef]

82. IFRWMO, Iranian Forests, Range and Watershed Management Organization National Land Use/Land Cover Map. Forest, Range and Watershed Management Organization of Iran, Tehran. 2014. Available online: https://www.frw.ir/02/En/StaticPages/Page. aspx?tid=13233 (accessed on 20 July 2014).

83. Prugh, L.R. An evaluation of patch connectivity measures. Ecol. Appl. 2009, 19, 1300-1310. [CrossRef]

84. Possingham, H.; Ball, I.; Andelman, S. Mathematical methods for identifying representative reserve networks. In Quantitative Methods for Conservation Biology; Springer: Berlin/Heidelberg, Germany, 2000; pp. 291-306.

85. Saaty, R.W. The analytic hierarchy process—what it is and how it is used. Math. Model. 1987, 9, 161-176. [CrossRef]

86. Janishevski, L.; Noonan-Mooney, K.; Gidda, S.B.; Mulongoy, K.J. Protected Areas in Today's World: Their Values and Benefits for the Welfare of the Planet; Technical Series; Secretariat of the Convention on Biological Biodiversity: Montreal, Canada, 2008; pp. 1-96.

87. Zuidema, P.A.; Sayer, J.A.; Dijkman, W. Forest fragmentation and biodiversity: The case for intermediate-sized conservation areas. Environ. Conserv. 1996, 23, 290-297. [CrossRef]

88. Abdolalizadeh, Z.; Ebrahimi, A.; Mostafazadeh, R. Landscape pattern change in Marakan protected area, Iran. Reg. Environ. Chang. 2019, 19, 1683-1699. [CrossRef]

89. Araújo, M.B.; Alagador, D.; Cabeza, M.; Nogués-Bravo, D.; Thuiller, W. Climate change threatens European conservation areas. Ecol. Lett. 2011, 14, 484-492. [CrossRef]

90. Brooks, T.M.; Mittermeier, R.A.; Mittermeier, C.G.; Da Fonseca, G.A.; Rylands, A.B.; Konstant, W.R.; Flick, P.; Pilgrim, J.; Oldfield, S.; Magin, G. Habitat loss and extinction in the hotspots of biodiversity. Conserv. Biol. 2002, 16, 909-923. [CrossRef] 
91. Téllez-Valdés, O.; DiVila-Aranda, P. Protected Areas and Climate Change: A Case Study of the Cacti in the Tehuacán-Cuicatlán Biosphere Reserve, México. Conserv. Biol. 2003, 17, 846-853. [CrossRef]

92. Hannah, L.; Midgley, G.; Andelman, S.; Araújo, M.; Hughes, G.; Martinez-Meyer, E.; Pearson, R.; Williams, P. Protected area needs in a changing climate. Front. Ecol. Environ. 2007, 5, 131-138. [CrossRef]

93. Scriven, S.A.; Hodgson, J.A.; McClean, C.J.; Hill, J.K. Protected areas in Borneo may fail to conserve tropical forest biodiversity under climate change. Biol. Conserv. 2015, 184, 414-423. [CrossRef]

94. Malakoutikhah, S.; Fakheran, S.; Hemami, M.-R.; Tarkesh, M.; Senn, J. Altitudinal heterogeneity and vulnerability assessment of protected area network for climate change adaptation planning in central Iran. Appl. Geogr. 2018, 92, 94-103. [CrossRef]

95. Yousefi, M.; Kafash, A.; Valizadegan, N.; Ilanloo, S.S.; Rajabizadeh, M.; Malekoutikhah, S.; Yousefkhani, S.S.H.; Ashrafi, S. Climate change is a major problem for biodiversity conservation: A systematic review of recent studies in Iran. Contemp. Probl. Ecol. 2019, 12, 394-403. [CrossRef]

96. Eustace, A.; Esser, L.F.; Mremi, R.; Malonza, P.K.; Mwaya, R.T. Protected areas network is not adequate to protect a critically endangered East Africa Chelonian: Modelling distribution of pancake tortoise, Malacochersus tornieri under current and future climates. PLoS ONE 2021, 16, e0238669. [CrossRef]

97. Thomas, C.D.; Gillingham, P.K.; Bradbury, R.B.; Roy, D.B.; Anderson, B.J.; Baxter, J.M.; Bourn, N.A.; Crick, H.Q.; Findon, R.A.; Fox, R. Protected areas facilitate species' range expansions. Proc. Natl. Acad. Sci. USA 2012, 109, 14063-14068. [CrossRef]

98. Geldmann, J.; Barnes, M.; Coad, L.; Craigie, I.D.; Hockings, M.; Burgess, N.D. Effectiveness of terrestrial protected areas in reducing habitat loss and population declines. Biol. Conserv. 2013, 161, 230-238. [CrossRef]

99. Hiley, J.R.; Bradbury, R.B.; Holling, M.; Thomas, C.D. Protected areas act as establishment centres for species colonizing the UK. Proc. R. Soc. B Biol. Sci. 2013, 280, 20122310. [CrossRef]

100. Haight, J.; Hammill, E. Protected areas as potential refugia for biodiversity under climatic change. Biol. Conserv. 2020, $241,108258$. [CrossRef]

101. Chen, Y.; Zhang, J.; Jiang, J.; Nielsen, S.E.; He, F. Assessing the effectiveness of China's protected areas to conserve current and future amphibian diversity. Divers. Distrib. 2017, 23, 146-157. [CrossRef]

102. Zhang, Z.; Sherman, R.; Yang, Z.; Wu, R.; Wang, W.; Yin, M.; Yang, G.; Ou, X. Integrating a participatory process with a GIS-based multi-criteria decision analysis for protected area zoning in China. J. Nat. Conserv. 2013, 21, 225-240. [CrossRef]

103. Zhang, P.; Dong, X.; Grenouillet, G.; Lek, S.; Zheng, Y.; Chang, J. Species range shifts in response to climate change and human pressure for the world's largest amphibian. Sci. Total Environ. 2020, 735, 139543. [CrossRef]

104. Wagner, N.; Harms, W.; Hildebrandt, F.; Martens, A.; Ong, S.L.; Wallrich, K.; Lötters, S.; Veith, M. Do habitat preferences of European fire salamander (Salamandra salamandra) larvae differ among landscapes? A case study from Western Germany. Salamandra 2020, 56, 254-264.

105. Wilk, A.J.; Donlon, K.C.; Peterman, W.E. Effects of habitat fragment size and isolation on the density and genetics of urban red-backed salamanders (Plethodon cinereus). Urban. Ecosyst. 2020, 23, 761-773. [CrossRef]

106. Milanovich, J.R.; Peterman, W.E.; Nibbelink, N.P.; Maerz, J.C. Projected loss of a salamander diversity hotspot as a consequence of projected global climate change. PLoS ONE 2010, 5, e12189. [CrossRef]

107. Lowe, W.H. Climate change is linked to long-term decline in a stream salamander. Biol. Conserv. 2012, 145, 48-53. [CrossRef]

108. Parra-Olea, G.; Martínez-Meyer, E.; De León, G.P.P. Forecasting climate change effects on salamander distribution in the highlands of central Mexico 1. Biotropica J. Biol. Conserv. 2005, 37, 202-208. [CrossRef]

109. Evans, A.E.; Urban, M.C.; Jockusch, E.L. Developmental temperature influences color polymorphism but not hatchling size in a woodland salamander. Oecologia 2020, 192, 1-10. [CrossRef]

110. Jacobsen, C.D.; Brown, D.J.; Flint, W.D.; Pauley, T.K.; Buhlmann, K.A.; Mitchell, J.C. Vulnerability of high-elevation endemic salamanders to climate change: A case study with the Cow Knob Salamander (Plethodon punctatus). Glob. Ecol. Conserv. 2020, 21, e00883. [CrossRef]

111. Ellison, A.; Zamudio, K.; Lips, K.; Muletz-Wolz, C. Temperature-mediated shifts in salamander transcriptomic responses to the amphibian-killing fungus. Mol. Ecol. 2020, 29, 325-343. [CrossRef]

112. Fusco, N.A.; Pehek, E.; Munshi-South, J. Urbanization reduces gene flow but not genetic diversity of stream salamander populations in the New York City metropolitan area. Evol. Appl. 2021, 14, 99-116. [CrossRef] [PubMed]

113. Pan, T.; Wang, H.; Yan, P.; Zhang, C.; Zhou, W.; Wu, X.; Zhang, B. The impact of stream landscape on genetic structure and dispersal patterns in stream salamander (Pachyhynobius shangchengensis). Asian Herpetol. Res. 2020, 11, $205-222$.

114. Antunes, B.; Velo-Antón, G.; Buckley, D.; Pereira, R.; Martínez-Solano, I. Physical and ecological isolation contribute to maintain genetic differentiation between fire salamander subspecies. Heredity 2021, 126, 1-14. [CrossRef] [PubMed]

115. Vaghefi, S.A.; Keykhai, M.; Jahanbakhshi, F.; Sheikholeslami, J.; Ahmadi, A.; Yang, H.; Abbaspour, K.C. The future of extreme climate in Iran. Sci. Rep. 2019, 9, 1464. [CrossRef] [PubMed]

116. Mousavi, A.; Ardalan, A.; Takian, A.; Ostadtaghizadeh, A.; Naddafi, K.; Bavani, A.M. Climate change and health in Iran: A narrative review. J. Environ. Health. Sci. Eng. 2020, 18, 367-378. [CrossRef]

117. Soltani, M.; Laux, P.; Kunstmann, H.; Stan, K.; Sohrabi, M.M.; Molanejad, M.; Sabziparvar, A.A.; Ranjbar SaadatAbadi, A.; Ranjbar, F.; Rousta, I.; et al. Assessment of climate variations in temperature and precipitation extreme events over Iran. Theor. Appl. Climatol. 2016, 126, 775-795. [CrossRef] 
118. Jowkar, H.; Ostrowski, S.; Tahbaz, M.; Zahler, P. The conservation of biodiversity in Iran: Threats, challenges and hopes. Iran. Stud. 2016, 49, 1065-1077. [CrossRef]

119. Daneshvar, M.R.M.; Ebrahimi, M.; Nejadsoleymani, H. An overview of climate change in Iran: Facts and statistics. Environ. Syst. Res. 2019, 8, 1-10.

120. Abbaspour, K.C.; Faramarzi, M.; Ghasemi, S.S.; Yang, H. Assessing the impact of climate change on water resources in Iran. Water Resour. Res. 2009, 45, 1-16. [CrossRef]

121. Thomas, C.D.; Gillingham, P.K. The performance of protected areas for biodiversity under climate change. Biol. J. Linn. Soc. 2015, 115, 718-730. [CrossRef]

122. Sahlean, T.; Gherghel, I.; Papes, M.; Strugariu, A.; Zamfirescu, Ş. Refining climate change projections for organisms with low dispersal abilities: A case study of the Caspian whip snake. PLoS ONE 2014, 9, e91994. [CrossRef]

123. Boyer, I.; Cayuela, H.; Bertrand, R.; Isselin-Nondedeu, F. Improving biological relevance of model projections in response to climate change by considering dispersal amongst lineages in an amphibian. J. Biogeogr. 2021, 48, 561-576. [CrossRef]

124. Subba, B.; Sen, S.; Ravikanth, G.; Nobis, M.P. Direct modelling of limited migration improves projected distributions of Himalayan amphibians under climate change. Biol. Conserv. 2018, 227, 352-360. [CrossRef]

125. Ashcroft, M.B. Identifying refugia from climate change. J. Biogeogr. 2010, 37, 1407-1413. [CrossRef]

126. Lucati, F.; Poignet, M.; Miró, A.; Trochet, A.; Aubret, F.; Barthe, L.; Bertrand, R.; Buchaca, T.; Calvez, O.; Caner, J. Multiple glacial refugia and contemporary dispersal shape the genetic structure of an endemic amphibian from the Pyrenees. Mol. Ecol. 2020, 29, 2904-2921. [CrossRef]

127. Afroosheh, M.; Rödder, D.; Mikulicek, P.; Akmali, V.; Vaissi, S.; Fleck, J.; Schneider, W.; Sharifi, M. Mitochondrial DNA variation and Quaternary range dynamics in the endangered Yellow Spotted Mountain Newt, Neurergus derjugini (Caudata, Salamandridae). J. Zool. Syst. Evol. Res. 2019, 57, 580-590. [CrossRef]

128. Malekoutian, M.; Sharifi, M.; Vaissi, S. Mitochondrial DNA sequence analysis reveals multiple Pleistocene glacial refugia for the Yellow-spotted mountain newt, Neurergus derjugini (Caudata: Salamandridae) in the mid-Zagros range in Iran and Iraq. Ecol. Evol. 2020, 10, 2661-2676. [CrossRef]

129. Teixeira, J.; Gonçalves, H.; Ferrand, N.; García-París, M.; Recuero, E. Mitochondrial phylogeography of the Iberian endemic frog Rana iberica, with implications for its conservation. Curr. Zool. 2018, 64, 755-764. [CrossRef]

130. Kearns, A.M.; Joseph, L.; Toon, A.; Cook, L.G. Australia's arid-adapted butcherbirds experienced range expansions during Pleistocene glacial maxima. Nat. Commun. 2014, 5, 1-11. [CrossRef]

131. Vaissi, S. Historic range dynamics in Kaisers's mountain newt (Neurergus kaiseri): Insights from phylogeographic analyses and species distribution modelling. Ecol. Evol. 2021, 1-12. [CrossRef]

132. Michalak, J.L.; Lawler, J.J.; Roberts, D.R.; Carroll, C. Distribution and protection of climatic refugia in North America. Conserv. Biol. 2018, 32, 1414-1425. [CrossRef]

133. Graham, V.; Baumgartner, J.B.; Beaumont, L.J.; Esperón-Rodríguez, M.; Grech, A. Prioritizing the protection of climate refugia: Designing a climate-ready protected area network. J. Environ. Plan. Manag. 2019, 62, 2588-2606. [CrossRef]

134. Stralberg, D.; Carroll, C.; Nielsen, S.E. Toward a climate-informed North American protected areas network: Incorporating climate-change refugia and corridors in conservation planning. Conserv. Lett. 2020, 13, e12712. [CrossRef]

135. Liu, J.; Linderman, M.; Ouyang, Z.; An, L.; Yang, J.; Zhang, H. Ecological degradation in protected areas: The case of Wolong Nature Reserve for giant pandas. Science 2001, 292, 98-101. [CrossRef]

136. Seiferling, I.S.; Proulx, R.; Peres-neto, P.R.; Fahrig, L.; Messier, C. Measuring protected-area isolation and correlations of isolation with land-use intensity and protection status. Conserv. Biol. 2012, 26, 610-618. [CrossRef] [PubMed]

137. Venter, O.; Brodeur, N.N.; Nemiroff, L.; Belland, B.; Dolinsek, I.J.; Grant, J.W. Threats to endangered species in Canada. Bioscience 2006, 56, 903-910. [CrossRef]

138. Fahrig, L.; Rytwinski, T. Effects of roads on animal abundance: An empirical review and synthesis. Ecol. Soc. 2009, 14, 1-20. [CrossRef]

139. Parsa, V.A.; Yavari, A.; Nejadi, A. Spatio-temporal analysis of land use/land cover pattern changes in Arasbaran Biosphere Reserve: Iran. Modeling Earth Syst. Environ. 2016, 2, 1-13. [CrossRef]

140. Kolahi, M.; Sakai, T.; Moriya, K.; Makhdoum, M.F. Challenges to the future development of Iran's protected areas system. Environ. Manag. 2012, 50, 750-765. [CrossRef] [PubMed]

141. Kelarestaghi, A.; Jeloudar, Z.J. Land use/cover change and driving force analyses in parts of northern Iran using RS and GIS techniques. Arab. J. Geosci. 2011, 4, 401-411. [CrossRef]

142. Bayne, E.M.; Habib, L.; Boutin, S. Impacts of chronic anthropogenic noise from energy-sector activity on abundance of songbirds in the boreal forest. Conserv. Biol. 2008, 22, 1186-1193. [CrossRef]

143. Varamesh, S.; Hosseini, S.; Rahimzadegan, M. Detection of land use changes in northeastern Iran by landsat satellite data. Appl. Ecol. Environ. Res. 2017, 15, 1443-1454. [CrossRef]

144. Jaafari, S.; Shabani, A.A.; Danehkar, A.; Nazarisamani, A. Landscape ecological metrics-based investigation of land cover/use changes in Khojir national park. Am. Eurasian J. Agric. Environ. Sci. 2013, 13, 168-173.

145. Newbold, T.; Hudson, L.N.; Hill, S.L.; Contu, S.; Lysenko, I.; Senior, R.A.; Börger, L.; Bennett, D.J.; Choimes, A.; Collen, B. Global effects of land use on local terrestrial biodiversity. Nature 2015, 520, 45-50. [CrossRef] 
146. Martínez, M.L.; Pérez-Maqueo, O.; Vázquez, G.; Castillo-Campos, G.; García-Franco, J.; Mehltreter, K.; Equihua, M.; Landgrave, R. Effects of land use change on biodiversity and ecosystem services in tropical montane cloud forests of Mexico. For. Ecol. Manag. 2009, 258, 1856-1863. [CrossRef]

147. Wright Jr, H.; McAndrews, J.H.; van Zeist, W. Modern pollen rain in western Iran, and its relation to plant geography and Quaternary vegetational history. J. Ecol. 1967, 415-443. [CrossRef]

148. Djamali, M.; De Beaulieu, J.-L.; Miller, N.F.; Andrieu-Ponel, V.; Ponel, P.; Lak, R.; Sadeddin, N.; Akhani, H.; Fazeli, H. Vegetation history of the SE section of the Zagros Mountains during the last five millennia; a pollen record from the Maharlou Lake, Fars Province, Iran. Veg. Hist. Archaeobotany 2009, 18, 123-136. [CrossRef]

149. Metzger, K.; Coughenour, M.; Reich, R.; Boone, R. Effects of seasonal grazing on plant species diversity and vegetation structure in a semi-arid ecosystem. J. Arid Environ. 2005, 61, 147-160. [CrossRef]

150. Dewi, S.; Van Noordwijk, M.; Ekadinata, A.; Pfund, J.-L. Protected areas within multifunctional landscapes: Squeezing out intermediate land use intensities in the tropics? Land Use Policy 2013, 30, 38-56. [CrossRef] 